invaluable resource for scholars. It should be of special interest to those working in the fields of antisemitism, early modern Iberian history, and the history and function of conspiracy theories.

\title{
Miriam Bodian
}

The University of Texas at Austin

bodian@austin.utexas.edu

DOI:10.1163/22141332-00603006-04

\section{Barbara B. Diefendorf}

Planting the Cross: Catholic Reform and Renewal in Sixteenth- and Seventeenth-

Century France. Oxford: Oxford University Press, 2019. Pp. xii + 215. Hb. \$74.0o.

In this impressive and engaging book, Barbara Diefendorf examines through six instructive local studies the efforts of regular clergy to reform and renew their communities in the face of the ravages of the French religious wars, and, in many cases, periods of internal decline that predated the wars. Drawing on often never-before used sources in local and departmental archives, Diefendorf uncovers a rich variety of contexts in which reform and renewal took shape driven both by the top-down efforts of leaders and bottom-up campaigns by local reformers and communities. With the exception of the Discalced Carmelites, this book focuses on religious orders that predated the religious wars or were established in France during the conflict. Thus, it places in the background the new religious orders that arrived in France in the seventeenth century and have received a disproportionate amount of scholarly attention to date. It offers a new and welcome perspective into the nature of Catholic renewal in France, one that firmly rejects efforts to generalize or describe a "typical" experience of regular clergy. "Catholic renewal" she argues "was a more diverse, experimental, and experiential process than we often recognize" (2).

Chapter one takes as its focus the three long-established female convents in the overwhelmingly Protestant city of Montpellier, tracing the fraught - and in two cases doomed-efforts by the nuns to survive and then renew their communities. All three foundations were severely disrupted by the wars through repeated expulsions, destruction of their buildings, loss of revenues, collapse in recruitment, and finally abandonment by local elites who preferred new female religious foundations. For these communities reform impulses were largely overwhelmed by the depravations of war. Chapter two shifts our attention to Paris, where the Feuillants house, the most prominent monastery of a recently established reformed group of Cistercians, broke with their 
royalist founder-abbot to enthusiastically support the Holy League. While on the surface political differences seem to define this conflict, Diefendorf deftly uncovers how it was also driven by a rejection of what some monks viewed as excessive ascetic practices imposed by their leader, casting new light on debates surrounding the important ideal of mortification of the flesh in the early Catholic Reformation. Chapter three examines how the Capuchins relied upon preaching, the promotion of new rituals and a dedication to public service when establishing themselves during the 158 os in Languedoc, one of the heartlands of the Huguenots. While successful in rallying and strengthening Catholic communities and instilling important aspects of what would become Catholic Reformation spirituality and ritual life, Diefendorf finds that their opportunities to convert Protestants were relatively limited by their inability to establish houses in Protestant cities.

If the first three chapters explore cases of religious communities swept up in France's religious wars, the last three shift focus to examine internal reform in older orders - the Dominicans and the Trinitarians - and the establishment of a new religious order - the Discalced Carmelites. Chapter four focuses on the efforts of Sébastien Michaëlis, the Dominican provincial of Occitanie, to reform his order from the top down and, in particular, his role in a notorious case of demonic possession, which resulted in the execution of Louis Gaufridy. Diefendorf convincingly argues that despite the conclusions of earlier scholars, Michaëlis's chief interest in publishing an account of the possession case was to protect his reputation and reform campaign even as he sought to expand its reach to Paris through the cultivation of patrons and supporters. Thus, this case study casts light on the challenges of reforming a well-established religious order from the top down against the wishes of some members and how one reforming leader sought to garner support for his movement through his involvement in the investigation of a case of demonic possession. Chapter five offers a very different case study of the Trinitarians of Provence whose rank and file membership attempted reform their order from the bottom up despite the determined opposition of their superior in Paris. Scholars have long viewed efforts to reform the Trinitarians in the seventeenth century as ineffective, but Diefendorf makes the compelling case that in the long run reforms did succeed in creating better educated, more fraternal, and more spiritual communities. She also shows how members of this older institution sought to engage with the new values and spirituality of the Catholic Reformation even though this was not strictly necessary for their primary mission of ransoming slaves. The competition for recruits with the new Catholic Reformation religious orders, a recurrent theme in this book, was one motivation for these spiritual reforms alongside the personal desires of individual Trinitarians. The final chapter 
returns to Paris and the establishment of a new order, the Discalced Carmelites, at the opening of the seventeenth century. One of the most interesting in the book, this case study explores how the Carmelite houses in Paris and Pontoise - the first to be founded in France-promoted alternative understandings of what constituted an ideal Carmelite community, casting light on how local circumstances shaped the creation of Catholic renewal foundations in new environments and the tensions that these differences could cause. The conclusion adroitly contextualizes the six case studies through comparison with other religious orders reinforcing and broadening the conclusion that there was no typical experience of Catholic renewal or reform even if some broad patterns emerge from the rich variety of local developments. The conclusion is worth special attention from readers as it sketches out many fruitful trails down that researchers should, and I hope will, venture in the future.

Those with a primary interest in the Jesuits might be frustrated by how little the Society features in this book. Still, some will find interesting the brief references to the adoption of Loyola's Spiritual Exercises by the Dominicans and the Trinitarians as they reformed the spiritual life of their foundations. Moreover, a careful reader will identify interesting parallels in the missions of the Jesuits and the Capuchins in Languedoc during the wars. Similarly, the factional splits within the Feuillants in Paris during the Holy League share many similarities to those experienced by the Jesuits. More generally, many will undoubtedly find inspiration in Diefendorf's local study approach, which offers intriguing possibilities for integrating the Jesuits into the nuanced and compelling story that she has sketched of the emergence of a "diverse, experimental, and experiential" Catholic renewal in France from the final decades of the sixteenth century.

\author{
Eric Nelson \\ Missouri State University \\ EricNelson@MissouriState.edu \\ DOI:10.1163/22141332-00603006-05
}

\title{
Jean-Pascal Gay
}

Le dernier théologien?: Théophile Raynaud (v. 1583-1663). Paris: Beauchesne, 2018. Pp. 488. $\mathrm{Pb}, € 41.00$.

Very very learned, indomitable, courageous, and incredibly energetic, the Lyonnais Jesuit, Raynaud (I shall henceforth refer to him as "R.") does not quite 